A.V.Dolgopolov, S.V.Donskov, Y.Fujii ${ }^{1}$, S.Inaba ${ }^{1}$, A.A.Lednev, T.Nakagawa ${ }^{4}$, Yu.D.Prokoshkin, H.Shimizu ${ }^{3}$, P.M.Shagin, A.V.Singovsky, V.P.Sugonyaev, K.Takamatsu ${ }^{2}$, T.Tsuru ${ }^{1}$

\title{
RESULTS OF A BEAM TEST OF THE COMBINED LEAD GLASS AND PWO CELLS DETECTOR FOR THE COMPASS ELECTROMAGNETIC CALORIMETER
}

\footnotetext{
${ }^{1}$ KEK, High Energy Accelerator Research Organization, Tsukuba, Ibaraki, 305, Japan. ${ }^{2}$ Faculty of Engineering, Miyazaki University, Miyazaki, 889-21, Japan.

${ }^{3}$ Department of Physics, Yamagata University, Yamagata, 990, Japan.

${ }^{4}$ Tohoku University, Aoba, Sendai, 980-77, Japan.
} 


\begin{abstract}
Dolgopolov A.V. et al. Results of a Beam Test of the Combined Lead Glass and PWO Cells Detector for the COMPASS Electromagnetic Calorimeter: IHEP Preprint 98-25. - Protvino, 1998. - p. 10, figs. 8 , tables 1 , refs.: 6 .

Results of a beam test of the combined PWO $\left(20 \times 20 \times 200 \mathrm{~mm}^{3}\right.$ in size $)$ and lead glass $\left(38 \times 38 \times 450 \mathrm{~mm}^{3}\right.$ in size $)$ cells for a COMPASS electromagnetic calorimeter prototype are described. The dependence of total energy deposited in a combined calorimeter as a function of distance L between front faces of lead glasses and PWO cells has been measured for electrons of different energies. An optimal value for $\mathrm{L}$ is obtained. The energy resolution is measured for the combined calorimeter. The position accuracy is estimated. The comparison of the measured characteristics of the calorimeter prototype with Monte Carlo simulation results is shown.
\end{abstract}

\title{
Аннотация
}

Долгополов А.В. и др. Результаты пучковых измерений комбинированного детектора на основе свинцового стекла и вольфрамата свинца для электромагнитного спектрометра COMPASS: Препринт ИФВЭ 98-25. - Протвино, 1998. - 10 с., 8 рис., 1 табл., библиогр.: 6.

Приведены результаты измерений на пучке комбинированного прототипа электромагнитного калориметра для эксперимента COMPASS на основе ячеек из вольфрамата свинца и свинцового стекла. Измерена зависимость полного энерговыделения в комбинированном калориметре от величины расстояния $L$ между передним краем стеклянных счетчиков и счетчиков из вольфрамата свинца. Найдено оптимальное значение параметра $L$. Измерено энергетическое разрешение комбинированного калориметра. Приведена оценка координатного разрешения. Показано хорошее согласие результатов измерений и моделирования методом Монте Карло.

(C) State Research Center of Russia Institute for High Energy Physics, 1998 


\section{Introduction}

One of the main goals of the COMPASS experiment at CERN SPS will be to study hadron structure and hadron spectroscopy by detecting high statistics samples of charmed particles and meson states in central collisions and Primakoff reactions [4]. To reach these objectives require the excelent calorimetry for gammas ranging between $100 \mathrm{MeV}$ and multi-100 GeV energies.

The calorimeter system of COMPASS experiment is composed of two electromagnetic calorimeters. GAMS-4000 [1] will be used as a first downstream electromagnetic calorimeter ECAL1. The central zone of the second ECAL2 electromagnetic calorimeter will be covered with a fine granulated detector made of the lead tungstate $\mathrm{PbWO}_{4}$ (PWO) heavy scintillating crystals, although a peripheral part of ECAL2, which surrounds the PWO calorimeter, will be made of the GAMS-type lead glass blocks.

The behaviour of the electromagnetic shower at the boundary between PWO and lead glass cells should be investigated. In this case the position of the PWO cell along the lead glass block plays a crucial role in changes of the calorimeter characteristics. To find an optimal position of the PWO cells along the lead glass counters is a main goal of the present beam test measurements. For that reason, a combined matrix of PWO and lead glass radiators were exposed in electron beams of different energies for various PWO positions along the axis.

Here the results of the beam test of the first ECAL2 calorimeter prototype are presented. The paper is organized as follows: in Section 2 a test beam setup and data selection are briefly described, in Section 3 the calibration procedure results are presented. The results are discussed in Section 4, with special emphasis on the total measured energy and energy resolution dependence on the PWO position. An electromagnetic shower shape and coordinate resolution for the boundary zone are briefly touched on in Section 5. Monte Carlo simulation results are presented in Section 6, which are compared with the results of Sections 4 and 5. Finally, Section 7 contains a summary and conclusions. 


\section{Beam test setup}

The beam test was performed on the X5 beam line of the CERN SPS with electrons in the energy range from 10 to $70 \mathrm{GeV}$. A sketch of the X5 test beam setup is shown in Fig. 1. The beam coming was defined by a coincidence signal of two scintilation counters $\mathrm{S} 1$ and $\mathrm{S} 2$. The $\mathrm{X}$ and $\mathrm{Y}$ coordinates of the incoming particles were measured with the scintillation hodoscope up to $1 \mathrm{~mm}$ accuracy, which was placed approximately $1 \mathrm{~m}$ upstream the prototype detector. The momentum bite $\Delta(p) / p$ was about $1 \%$ at X 5 beam line.

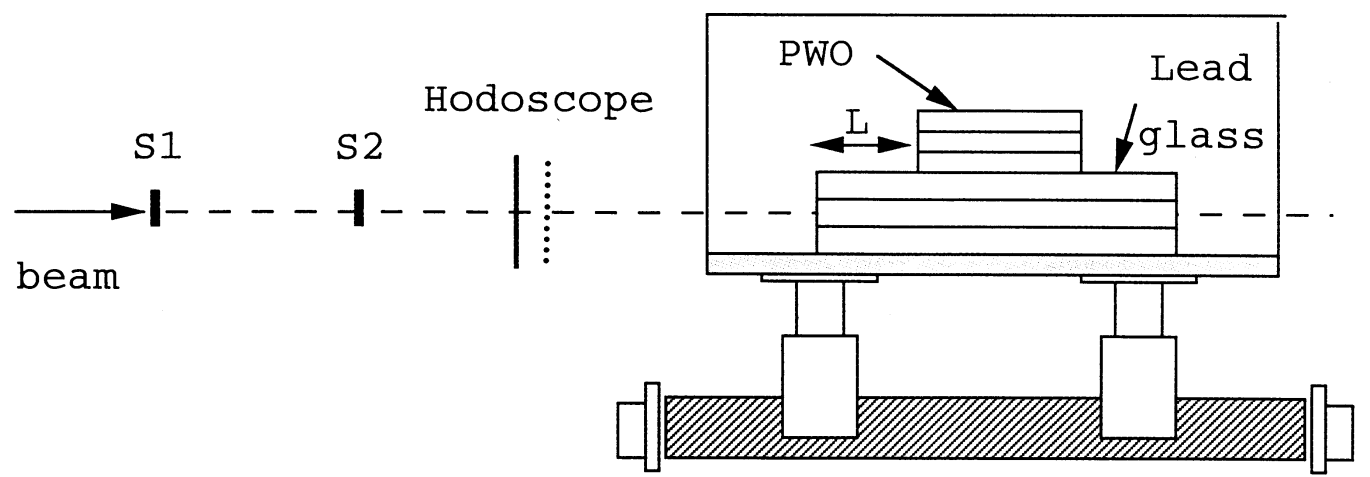

Fig. 1. The experimental setup of CERN X5 beam line.

Three kinds of triggers were used:

- Beam. A beam event was the coincidence of the two scintillation counters S1 and S2 shown in Fig.1.

- Pedestal. We recorded pedestals events inside and outside the accelerator cycle.

- Monitoring. The photomultipliers gain was monitored using a light emitting diode (LED) triggered by externally generated signals.

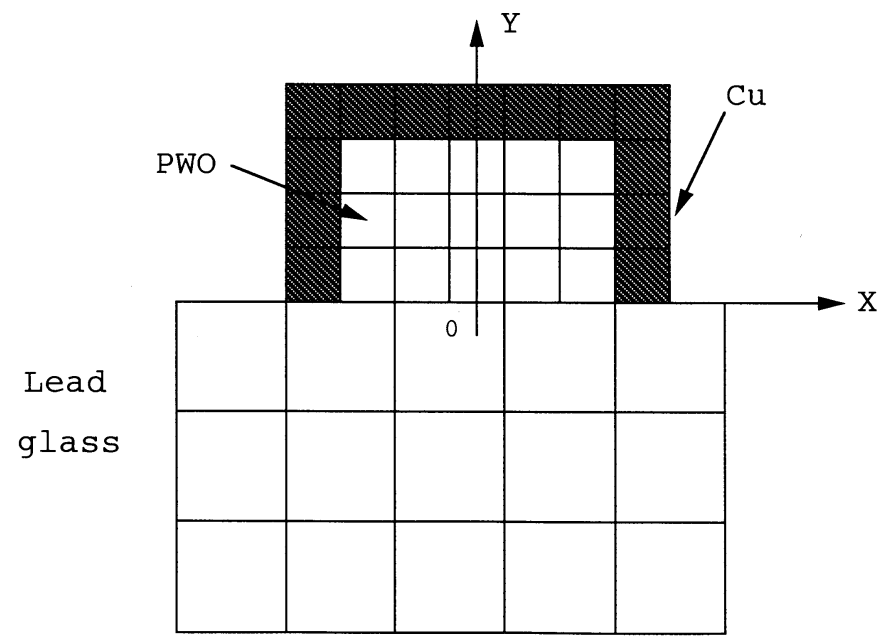

Fig. 2. The arrangement of PWO and lead glass cells in a prototype detector.
For data taking the DAQ system included a VME based CETIA UNIX workstation and a VME crate equipped with a FIC8232 single board computer and a CAMAC branch driver. The FIC reads events (1.5 Kbits/event) during $2.5 \mathrm{~s}$ accelerator beam spill and optionally writes them with a speed up to 1000 events/s on the DLT tape. The CETIA workstation was used for the setup control and data monitoring. The pedestals were written on the tape during the accelerator cycle, both inside and outside the beam spill (twice before spill, 25 inside the spill and after the spill). 
The prototype detector was composed of 15 PWO cells and 15 lead glass blocks arranged each in $3 \times 5$ arrays. The drawing of the prototype matrix is shown in Fig. 2 .

The PWO cell have a shape of rectangular prism $20 \times 20 \times 200 \mathrm{~mm}^{3}$ in size $\left(22.2 X_{o}\right.$ long). Each crystal was wrapped in Tyvek paper and viewed with a HAMAMATSU R4125 PMT coupled to the crystal with Dow Corning $Q_{2}-3067$ optical compound. PWO cells were surrounded by $\mathrm{Cu}$ plates on three sides (see Fig. 2) water cooled for the temperature stabilization purpose. The temperature was measured with two sensors: the former located in air near the crystals, the latter was coupled on the crystals to follow PWO temperature variations.

The lead glass part of the prototype was composed of GAMS-type lead glass blocks $38 \times 38 \times 450 \mathrm{~mm}^{3}$ in size. Each lead glass block was wrapped into aluminized Mylar and viewed with FEU-84 PMT. At the fronts of the PWO and lead glass cells the optical fibers of the LED monitoring system were mounted.

The PMT signals were read out through $50 \mathrm{~m}$ coaxial cables to 12-bit CAMAC QDC [3] with 120 ns gate.

The prototype calorimeter was installed on the manually controlled movable platform for the purpose of calibration in the electron beam and displacement across the beam line.

The data were collected under different run conditions. The position of PWO cells along the axis of lead glass blocks $\mathrm{L}$ was changed from 0 up to $140 \mathrm{~mm}$. For each value of $\mathrm{L}$ the data were collected for an energy range from 10 up to $70 \mathrm{GeV}$.

\section{Calibration}

The calibration of the prototype calorimeter was performed with a $20 \mathrm{GeV}$ electron beam. All the PWO and lead glass cells were irradiated by electron beam with a spot size $2 \times 2 \mathrm{~cm}^{2}$. Calibration was repeated after every change in a prototype arrangement. Calibration coefficients were calculated according to the conventional GAMS procedure described in [5]. The calibration coefficients were used in the total energy measurements for various electron energies.

\section{Results}

The prototype calorimeter was irradiated by electrons of different energies from 10 to $70 \mathrm{GeV}$. The position of PWO cells along the lead glasses varied from 0 up to $140 \mathrm{~mm}$ for each value of beam energy. The sum of calibrated amplitudes was used as a measured total energy released in the detector

$$
E_{t}^{j}=\sum_{i=1}^{30} c_{i} A_{i}^{j}
$$

where $c_{i}$ is a calibration coefficient for $i$ th cell; $A_{i}^{j}$ is an amplitude in $i$ th cell and $E_{t}^{j}$ is total energy sum for $j$ th event. 
In the region of the border between PWO and lead glasses the total energy depends on the point of the impact incoming electrons $X$ and position of PWO crystals along the lead glass blocks $L$. The value of $Y$ was measured with scintillation hodoscope with $1 \mathrm{~mm}$ accuracy. For each value of $Y$ the total energy spectrum was fitted by Gaussian with three free parameters. The fitted values were used and plotted. Fig.3 shows the dependence of relative total energy $E_{t} / E_{o}$ on $Y(\mathrm{X}=0)$ for 20 and $70 \mathrm{GeV}$ electrons at $\mathrm{L}=0 \mathrm{~mm}$. The data for $70 \mathrm{GeV}$ electrons show clearly a lateral leakage effect when approaching the detector borders. So, for the purpose of further analysis, the $20 \mathrm{GeV}$ data sample was selected.

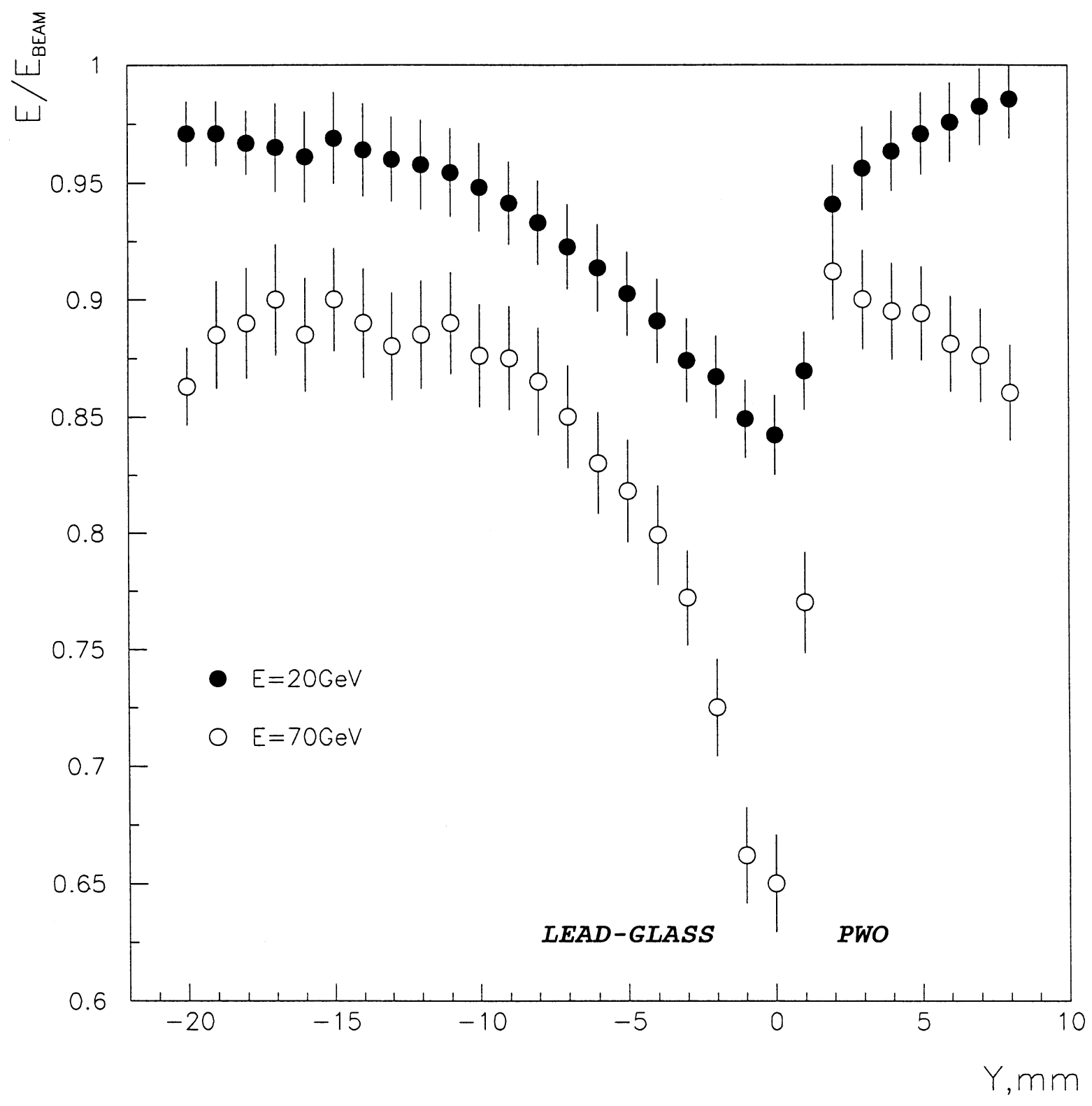

Fig. 3. Relative total energy for electrons of 20 and $70 \mathrm{GeV}$ as function of $Y$-electron position for $L=0 \mathrm{~mm}$. 
Dependence of the relative total energy on the value of $L$ is shown in Fig.4. Relative total energy drops near the border significantly, by more than $15 \%$ due to a bad energy leakage in the region behind the PWO crystals. That leakage effect decreases with $L$ increasing and constitutes $5 \%$ and $4 \%$ for $\mathrm{L}=80$ and $140 \mathrm{~mm}$, accordingly. The value of $L=80 \mathrm{~mm}$ seems to be optimal as appropriate position of PWO crystals.

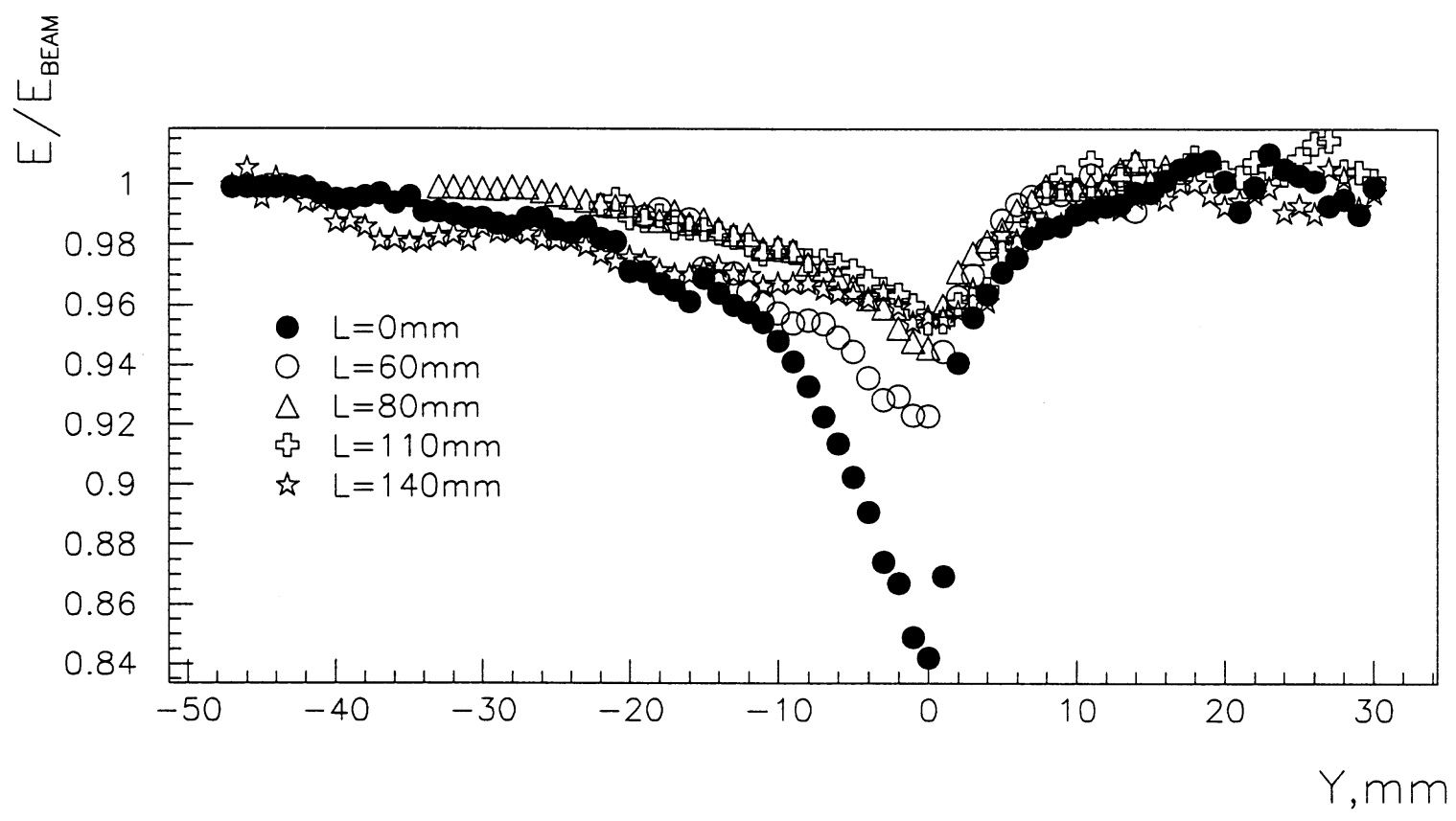

Fig. 4. Dependence of the relative measured energy on value of $L$ for $20 \mathrm{GeV}$ electrons.

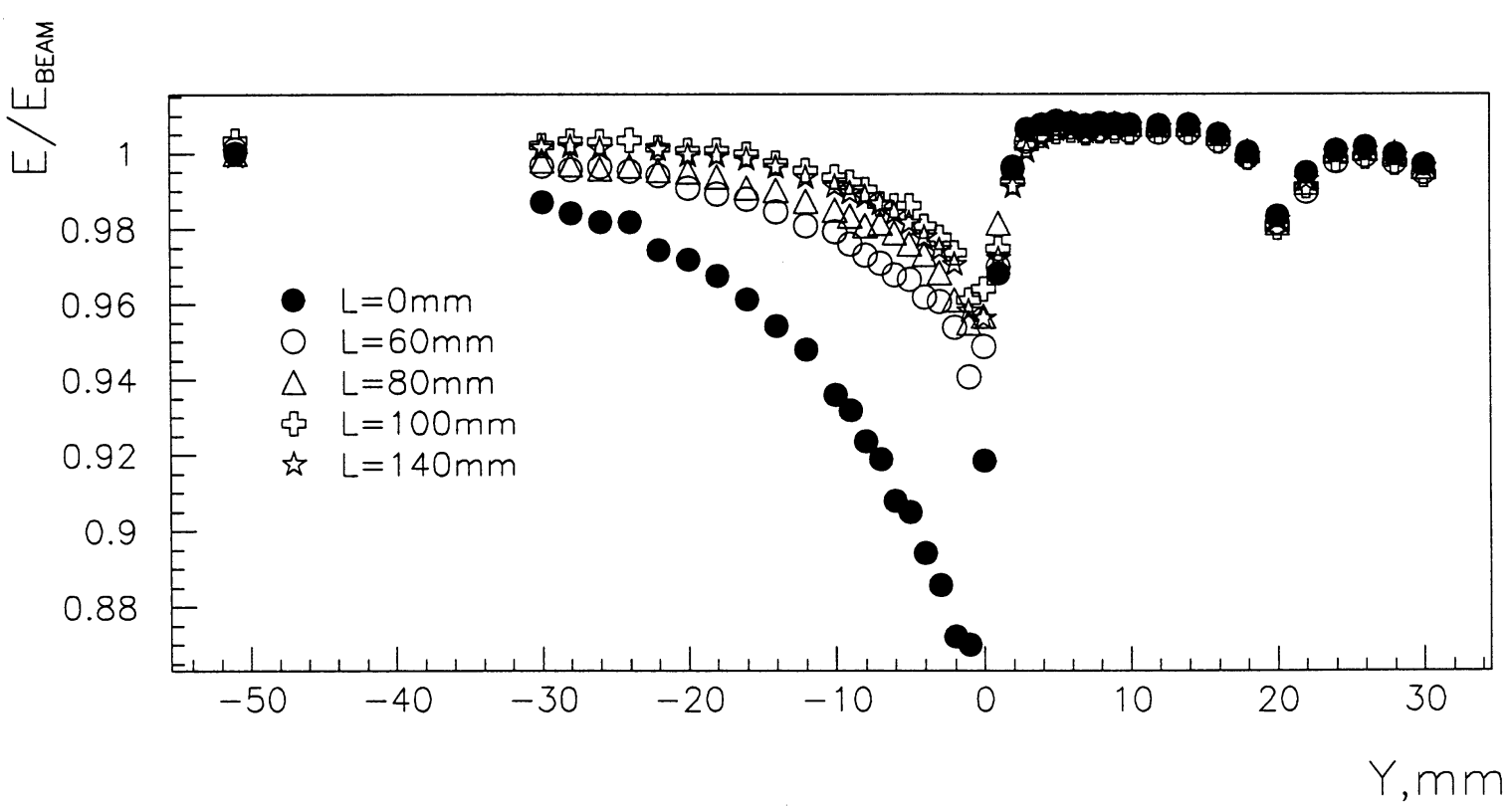

Fig. 5. Monte Carlo simulation of the relative measured energy for $20 \mathrm{GeV}$ electrons for different values of $L$. 
The spectra show different behaviour for the left and right wings respective to the bottom point. Left part shows smoother rise compared to the right one. This difference is partly explained by the different electromagnetic shower development both longitudinal and lateral in PWO and lead glass cells.

The energy resolution measured for $L=80 \mathrm{~mm}$ are plotted in Fig. 6 as the dependence on $Y$. Resolution demonstrates a somewhat different behaviour against the total energy. It deteriorates by about $20 \%$ in the $\sim 12 \mathrm{~mm}$ zone at the boundary between PWO and lead glass cells.
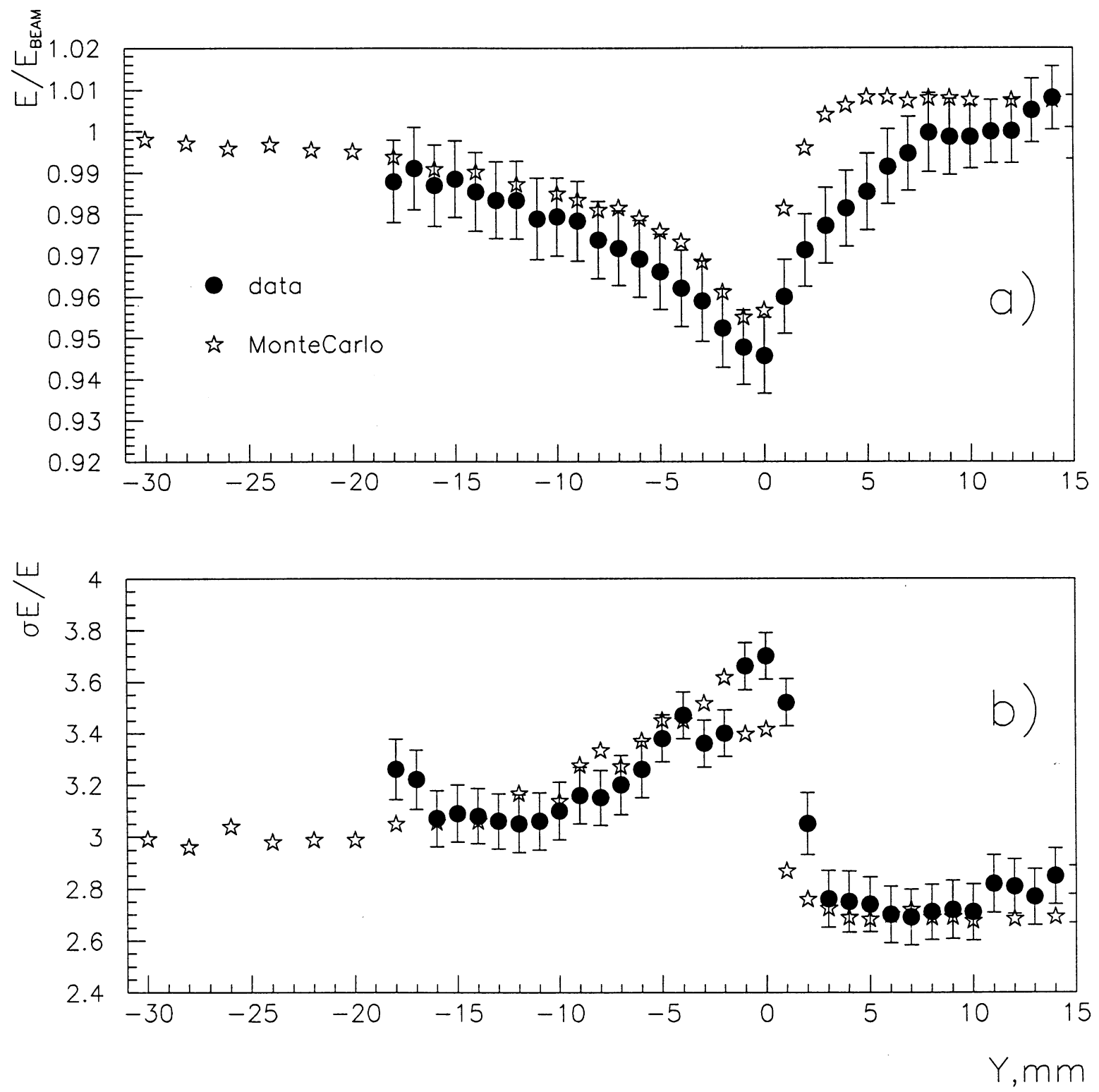

Fig. 6. Measured and Monte Carlo simulated energy resolution as function of $20 \mathrm{GeV}$ electron position $Y$ for $L=80 \mathrm{~mm}$. 


\section{Coordinate measurement}

The calculation of the shower center of gravity is the simplest method to measure particle coordinate $[2]$ :

$$
X_{c}^{j} . g .=\frac{\sum_{i=1}^{30} E_{i}^{j} X_{i}}{\sum_{i=1}^{30} E_{i}^{j}},
$$

where $E_{i}^{j}$ is the deposited energy in the $i$-th cell for the event number $j, X_{i}$ is the coordinate of the center of $i$-th cell. This sum expands over all the detector.

The PWO and lead glass arrays $(3 \times 5+3 \times 5)$ were irradiated uniformly with electrons over a region approximately $85 \times 25 \mathrm{~mm}^{2}$ to measure the coordinate resolution of the detector. The coordinate of incoming particles was measured using a scintillation hodoscope with $1 \mathrm{~mm}$ resolution.

Since lateral cell dimensions compares with electromagnetic lateral shower size at that medium, a sufficient amount of shower energy releases in one cell. It results in nonlinear relationship between the measured and reconstructed coordinates [6] as is shown in Fig.7, which gives a large bias in a coordinate estimate. In order to remove such a systematic effect the correction to these data can be performed using the GAMS coordinate reconstruction procedure [6]. After the correction the coordinate estimate seems unbiased and linear-dependent on the measured coordinate.

The coordinate resolution is also expected to be a function of the coordinate with respect to the center of the cell. This behaviour is shown in Fig. 8 for the position of PWO cells along lead glasses blocks $\mathrm{L}=80 \mathrm{~mm}$. A factor by 3 variation for the coordinate resolution is found between the center and the edge of the cell, which is natural for the method used [1]. No deterioration in the coordinate accuracy at the boundary between PWO and lead glass cells is seen in Fig.8.

\section{Monte Carlo simulation data}

In order to understand the behaviour near the boundary in detail, the Monte Carlo simulation is performed on the base of the GEANT 3.21 simulation package. A full beam test geometry was implemented as well as injected beam characteristics. These parameters are summarized in Table 1.

Table 1. Used simulation parameters.

\begin{tabular}{|c|c|c|c|c|c|c|}
\hline & $\begin{array}{c}\text { Module Sizes } \\
\mathrm{X}(\mathrm{cm}), \quad \mathrm{Y}(\mathrm{cm}), \mathrm{Z}(\mathrm{cm})\end{array}$ & $\begin{array}{l}\text { Array Size } \\
\mathrm{Nx} \mathrm{Ny}\end{array}$ & $\begin{array}{l}\text { R.L. } \\
(\mathrm{cm})\end{array}$ & $\begin{array}{l}\text { Density } \\
\left(\mathrm{g} / \mathrm{cm}^{3}\right)\end{array}$ & $\begin{array}{c}\text { Np.e. } \\
(\mathrm{n} / \mathrm{MeV})\end{array}$ & $\begin{array}{l}\text { Attn.L. } \\
(\mathrm{cm})\end{array}$ \\
\hline Lead Glass & 45.00 & 3 & 2.80 & 3.62 & 0.8 & 200.0 \\
\hline $\mathrm{PbWO}_{4}$ & 20.00 & 3 & 0.89 & 8.28 & 2.0 & 35.0 \\
\hline $\mathrm{PbWO}_{4}$ back-shift & $0,4,6,8,10,14 \mathrm{~cm}$ & & & & & \\
\hline Wrapper thickness & $0.019 \mathrm{~cm}$ & & Cry & tal Gap 0 & $\mathrm{~mm}$ & \\
\hline $\begin{array}{l}\text { Generated Electron } \\
\text { Momentum }\end{array}$ & $\begin{array}{l}P_{x}=0.0 \mathrm{GeV} \\
P_{y}=0.0 \mathrm{GeV} \\
P_{z}=20.0 \mathrm{GeV}\end{array}$ & & & $\begin{array}{l}\sigma_{T_{P_{x} / P}}=0.2 \\
\sigma_{P_{x} / P}=0.2 \\
\sigma_{P_{z} / P}=1 .\end{array}$ & & \\
\hline Generated Vertex & $\begin{array}{l}\sigma_{V_{x}}=0.1 \mathrm{~cm} \\
\sigma_{V_{u}}=0.1 \mathrm{~cm}\end{array}$ & & & & & \\
\hline
\end{tabular}




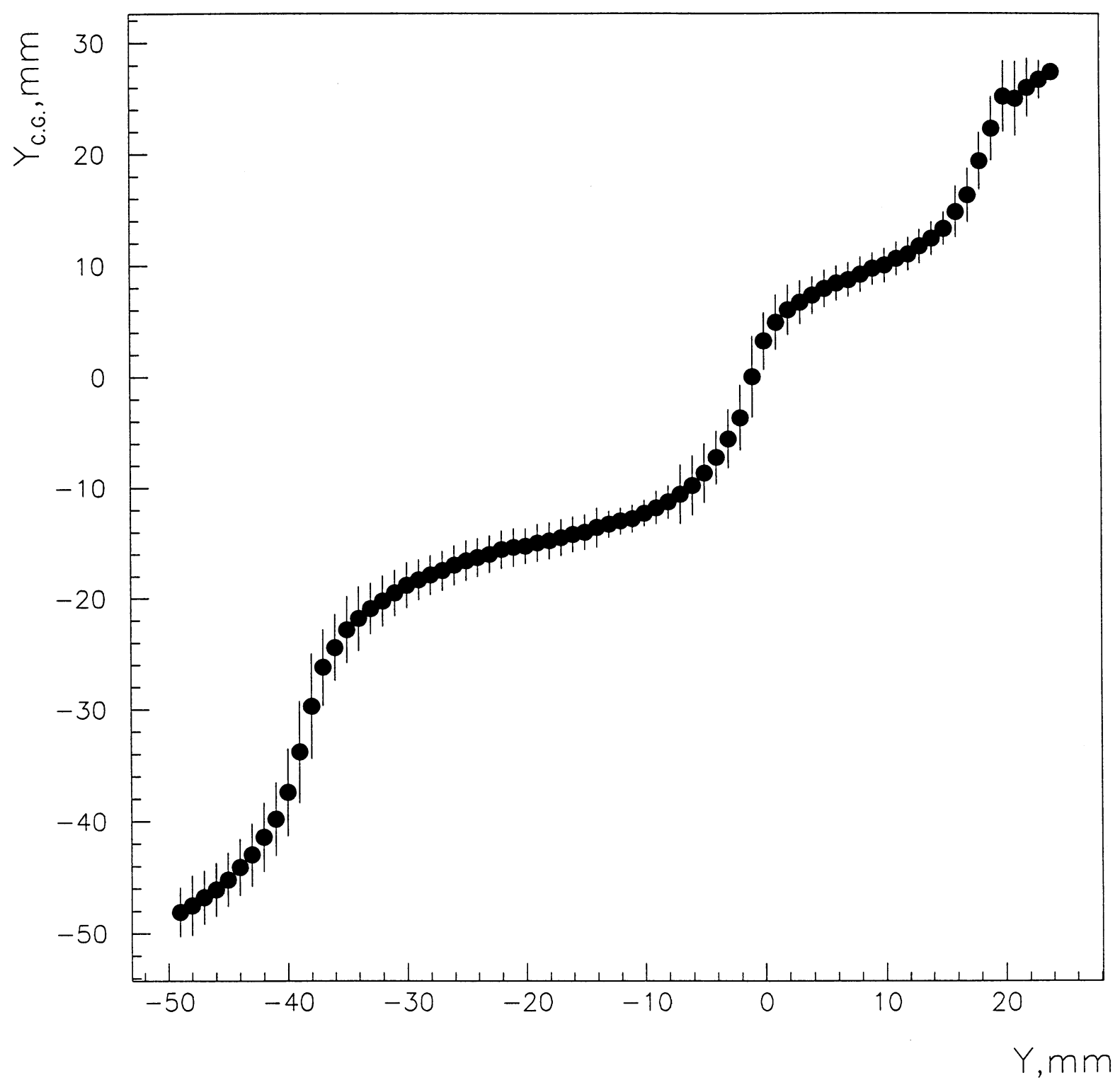

Fig. 7. Electromagnetic shower center of gravity as dependence of electron position $Y$. 


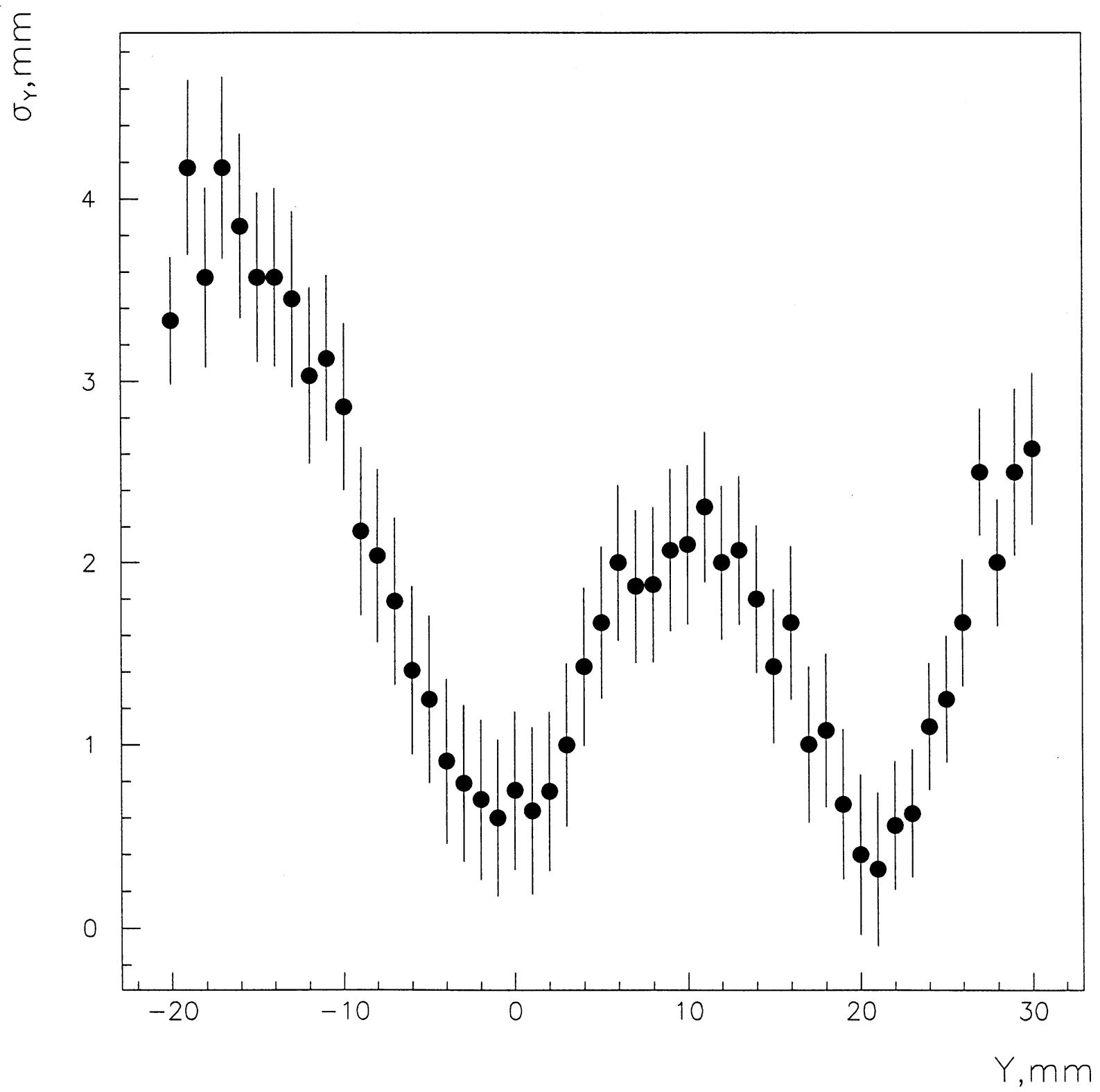

Fig. 8. Coordinate resolution of the prototype.

The simulation results of measured energy are shown in Fig.5 for various $L$ 's. Though simulation gives less deterioration than the beam test, the $L$-dependences are quite similar. Also the simulated energy resolution for $L=80 \mathrm{~mm}$ yields shown in Fig.6. For the simulated energy resolution, a constant term of $2.4 \%$ is added quadratically in order to reproduce the energy resolution of the beam test result in the lead glass array center.

The simulation for sufficiently large crystal array was also carried out and it gave a similar $L$-dependence as well. The simulation, thus, supports the conclusion that $L=80 \mathrm{~mm}$ is the optimum. 


\section{Summary and conclusions}

The beam test of an electromagnetic calorimeter prototype for the COMPASS CERN SPS experiment has been performed. The total energy and resolution behaviour at the boundary between PWO and lead glass cells was measured.

The deterioration of detector characteristics occurs in a small region (about 10-15 mm) near the boundary of PWO and lead glass. The total energy decreased down by $15 \%$ depending strongly on the value of the PWO position along the lead glass axis. The value of $L=80 \mathrm{~mm}$ for that position seems to be optimal for energy measurements. The energy resolution for optimal value of $L$ gets worse by $20 \%$ in the region of PWO and lead glass boundary.

There was not found the deterioration in the coordinate resolution at the boundary.

The results are in a good agreement with the Monte Carlo simulation data.

The energy and coordinate resolution satisfy the COMPASS experiment requirements even taking into account the deterioration in the detector characteristics at the boundary between PWO cells and lead glass blocks. For precise measurements of the coordinate resolution and shower profile, an expanded number of PWO and lead glass cells needed.

\section{Acknowledgements}

The authors are deeply thankful to the CERN, IHEP and KEK Directorates for the support of the present work.

\section{References}

[1] F.Binon et al., Nucl. Instr. and Meth. 248 (1986) 86.

[2] G.A.Akopdjanov et al., Nucl. Instr. and Meth. 140 (1977) 441.

[3] D.Alde et al., Nucl. Instr. and Meth. A240 (1986) 343.

[4] The COMPASS Collaboration, Preprint CERN/SPSLC 96-14, Geneva (1996).

[5] A.A.Lednev, Preprint IHEP 93-153, Protvino (1993).

[6] A.A.Lednev, Nucl. Instr. and Meth. A364 (1995) 307.

Received 10 April 1998 
А.В.Долгополов и др.

Результаты пучковых измерений комбинированного детектора на основе свинцового стекла и вольфрамата свинца для электромагнитного спектрометра COMPASS.

Оригинал-макет подготовлен с помощью системы $\mathrm{LAT}_{\mathrm{E}} \mathrm{X}$. Редактор Е.Н.Горина.

Технический редактор Н.В.Орлова.

Подписано к печати 10.04.98. Формат $60 \times 84 / 8 . \quad$ Офсетная печать. Печ.л. 1,25. Уч.-изд.л. 0,96. Тираж 180. Заказ $136 . \quad$ Индекс 3649. ЛР №020498 17.04.97.

ГНЦ РФ Институт физики высоких энергий 142284, Протвино Московской обл. 
Индекс 3649

П Р Е П Р И Н Т 98-25,

И Ф В Э, 